(c) American Dairy Science Association, 2004.

\title{
The Use of Test Day Information to Predict Energy Intake of Dairy Cows in Early Lactation
}

\author{
C. Heuer \\ Massey University, Palmerston North, New Zealand 11222
}

\begin{abstract}
This study aimed to validate a previously developed model for the estimation of energy balance in high producing dairy cows from test day information during the first $12 \mathrm{wk}$ of lactation. Monensin (an ionophor) increases the energy status of dairy cows. Gold standard for the validation was a higher energy status, indicated by lower blood ketone body concentrations, lower percent milk fat, and higher milk-yield of monensin-supplemented than control cows in 8 randomized block design feeding trials. Estimated energy intake $\left(\mathrm{eE}_{\text {intake }}\right)$ was calculated as estimated energy balance (eEB) plus energy in actual milk produced (in units of $\mathrm{MJ}_{\text {nel }}$ ) plus a constant or variable amount of energy required for maintenance. The variable amount was based on BW, while the constant was the average BW in each parity group $(1,2,3,4+)$. Both $\mathrm{eEB}$ and $\mathrm{eE}_{\text {intake }}$ were compared between groups of cows with and without monensin supplementation ( $\mathrm{n}=600$ lactations). The trials started with a presupplement period during lactation wk 2 to 5 followed by a supplementation period during lactation wk 6 to 12. During the presupplement period, both $\mathrm{eEB}$ and $\mathrm{eE}_{\text {intake }}$ were similar for all cows. At 2, 3, and 8 wk after starting the monensin supplementation, the eEB of the supplemented cows was significantly higher, while $\mathrm{eE}_{\text {intake }}$ was significantly higher throughout the supplementation period. The results were similar for the 2 methods of calculating energy for maintenance, variable or constant. The feed conversion efficiency, calculated as $\mathrm{kg}$ of fat-protein corrected milk per $\mathrm{MJ}_{\text {nel }}$ of $\mathrm{eE}_{\text {intake, }}$ was highest in first calving cows compared with cows having more lactations, and correlated with standard milk production at trial group level. It was concluded that $\mathrm{eE}_{\text {intake }}$ was a valid measure of net energy absorption.
\end{abstract}

(Key words: predicting energy balance, herd test data, dairy herd)

Abbreviation key: ACAC = acetoacetate, $\mathbf{B H B}=$ betahydroxy-butyrate, $\mathbf{e E B}$ = estimated energy balance,

Received July 18, 2003.

Accepted October 3, 2003.

Corresponding author-e-mail: c.heuer@massey.ac.nz.
eEI = estimated energy intake, FPCM = fat-proteincorrected milk.

\section{INTRODUCTION}

Energy intake below requirement occurs frequently in dairy cows during early lactation and is a consequence of insufficient DMI or lack of high quality feed. Fat condition at calving, calving stress, and a sudden change from roughage-based to energy-dense rations in transition from the dry period to early lactation are regarded as the main causes of insufficient DMI (Goff and Horst, 1997; Drackley, 1999; Kennelly et al., 1999). Lack of high quality feed often arises during seasonal feed shortages in pastoral dairy production systems at times when pasture growth cannot cope with lactation demand or pasture DMI is too low because cows cannot eat enough pasture. Lack of energy predisposes dairy cows for diseases and poor reproduction performance (Gearhart et al., 1990; Senatore et al., 1996, Heuer et al., 1999; Reksen et al., 2001).

Dairy managers need to be aware of low energy intake at an early stage to make supplements available in time. However, ration design or feed budgeting often fail to predict DMI accurately (Simensen et al., 1990; De Kruif et al., 1998). Due to seasonal effects and management changes, the feed quality and DMI of a dairy herd can be highly variable over time. Therefore, parameters are needed for repeated monitoring of DMI and energy balance. Monitoring of the metabolic status of dairy cows has been studied extensively. Indicators of metabolic changes were ketone bodies in serum or milk, daily milk production, or BCS. However, all of these were regarded as relatively insensitive, producing a high number of false positives, expensive, labor intensive, or required invasive manipulations (Mottram, 1997; Heuer et al., 2000).

Recently, it was postulated that the response of the cow, i.e., the production of milk and solids, reflects energy balance, thus providing a low cost means for regular monitoring. It was suggested to use data from regular milk control for the monitoring of energy balance (Svennersten-Saunja et al., 1997; De Kruif et al., 1998). A model for the prediction of energy balance at herd level was developed and validated (Heuer et al., 2000, 
2001a). For large herds of over 200 cows, the model provided precise and accurate estimates of energy balance. The interpretation of the predictions however depended on the current and previous milk production, e.g., a herd could have a high energy balance, either because DMI was high (high supply) at optimal milk production in response to adequate feeding, or because DMI was moderate and milk production was low (low demand) in response to inadequate feeding. It was therefore desirable to adjust the predicted energy balance for the level of milk production.

The current study aimed to again validate the previously developed model for the estimation of energy balance (eEB). It was further intended to adjust eEB for milk production by estimating energy intake (eEI). Data from a clinical trial on the effect of monensin on milk production, health and fertility were used to validate eEB and eEI. It was hypothesised that the estimates would accurately predict the difference in energy status between cows supplemented with monensin and nonsupplemented control cows.

\section{MATERIALS AND METHODS}

\section{Feeding Trials}

Eight feeding trials were carried out by research institutions in The Netherlands, France, and England to test the effect of monensin premix (Rumensin G 100 Premix, Elanco Animal Health) on milk production, health, and fertility. Details of trial design, experimental conditions, cows, and data recording were described elsewhere (Van der Werf et al., 1998, Phipps et al., 2000; Heuer et al., 2001b). In brief, 600 cows were allocated to treatment (150,300, or $450 \mathrm{mg} / \mathrm{d}$ of monensin) or control (placebo) in a randomized block design. Blocking factors were parity, time of calving, and level of milk production. This study does not differentiate effects of different monensin doses because a previous report showed that all doses had significant and similar effects on milk production (Van Der Werf et al., 1998). Data on milk production were collected during an approximate period of $5 \mathrm{wk}$ prior to treatment ( $8 \mathrm{wk}$ in trial 5). Thereafter, monensin was mixed in the concentrate and fed for periods of 112 to $224 \mathrm{~d}$. The observation period of this study included week 2 to 12 of lactation.

The roughage consisted of a mixed grass-maize silage in ratios varying from 8:2 to 0:1 supplemented by commercial dairy concentrates to meet the requirement for, in most trials, $40 \mathrm{~kg}$ of fat-protein corrected milk (FPCM; Table 1). The roughage was either mixed with the concentrate and fed ad libitum as a TMR or measured and fed to every cow individually twice a day. Two trials changed from stall feeding in winter to pasture in summer (trials 4 and 7 of Table 1). Test feeds were either spread manually over the TMR (trials $1,3,4$, and 8), dosed automatically in the milking parlour (trial 6) or allocated to individual cow by automatic feed stations (trials 2, 5, and 7). Orts were weighed to determine the amount of monensin not eaten; the monensin concentration in the test feeds was monitored by daily sampling and testing of one pooled sample per week.

Milk production was measured twice a day. Morning and evening milk samples were collected once a week (once every $4 \mathrm{wk}$ in trial 8), and percent fat and protein were determined on pooled a.m. and p.m. samples by a regional DHI laboratory. At 2- to 4 -wk intervals, a blood sample was collected and assayed for aceto-acetate (ACAC) and beta-hydroxy-butyrate (BHB).

\section{Data Analysis}

Energy balance (EB) in units of $\mathrm{MJ}_{\text {nel }}$ were defined as the difference between daily energy intake and requirement:

$$
\mathrm{EB}=\mathrm{E}_{\text {intake }}-\mathrm{E}_{\text {requirement }} \quad\left(\mathrm{MJ}_{\text {nel }} / \mathrm{d}\right)
$$

Energy balance was replaced by eEB. Previous research by Heuer et al. (2000, 2001a) has defined an eEB equation based on parity, lactation week, and milk composition volume as follows:

Equation 1:

$$
\begin{gathered}
\mathrm{eEB}=217.8-\mathrm{wk} 2 \times 31.9-\mathrm{wk} 3 \times 20.6-\mathrm{wk} 4 \times 15.6 \\
-\mathrm{wk} 5 \times 11.5-\mathrm{wk} 6 \times 8.0-\mathrm{wk} 7 \times 10.6-\mathrm{wk} 8 \times 7.2 \\
-\mathrm{wk} 9 \times 5.3-\mathrm{wk} 10 \times 4.0-\mathrm{wk} 11 \times 2.7-\mathrm{wk} 12 \times 0 \\
- \text { par } 1 \times 34.9-\text { par } 2 \times 7.2-\text { par } 3 \times 6.7-\text { par } 4 \times 0 \\
- \text { milk } \times 2.11-\text { prot } \times 15.36-\mathrm{FP} \\
\times 49.24 \quad\left(\mathrm{MJ}_{\text {nel }} / \mathrm{d}\right)
\end{gathered}
$$

where: wk2 to wk12 = dummy variable (values 1 or 0 ) for lactation wk 2 to 12 , par 1 to par4 = dummy variable for parity 1 to 4 , milk = kg milk/d, prot = percent protein in milk, and FP = ratio of percent fat over percent protein. For example, if a cow of parity 2 was in lactation wk 5 and had $3.1 \%$ protein, $3.6 \%$ fat, and $30 \mathrm{~kg}$ of milk, the estimated energy balance was:

$$
\begin{gathered}
\mathrm{eEB}=217.8-11.5-7.2-30 \times 2.11-3.1 \times 15.36 \\
-3.6 / 3.1 \times 49.24=31.0 \mathrm{MJ}_{\mathrm{nel}} / \mathrm{d} .
\end{gathered}
$$

Further quantities used in calculations were defined according to the Dutch feeding system (Van Es, 1978; Van Der Honing and Alderman, 1988) that is based on the Dutch feeding value per unit of milk (VEM); the VEM is equivalent to 0.006069 unit of $\mathrm{MJ}_{\text {nel }} / \mathrm{d}$, thus:

$$
\mathrm{FPCM}=(0.337+0.116 \times \% \text { fat }+0.060 \times \% \text { protein })
$$


Table 1. Description of feeding trials.

\begin{tabular}{|c|c|c|c|c|c|c|}
\hline $\begin{array}{l}\text { Trial } \\
\text { number } \\
\text { no. }\end{array}$ & $\begin{array}{l}\text { Number of } \\
\text { lactations } \\
\text { no. }\end{array}$ & $\begin{array}{l}\text { Calving } \\
\text { period } \\
\text { Month/Year }\end{array}$ & $\begin{array}{l}\text { Parity } \\
\text { no. }\end{array}$ & $\begin{array}{l}\text { Start of } \\
\text { suppl. } \\
\text { DIM }\end{array}$ & $\begin{array}{l}\text { Sampling } \\
\text { period } \\
\text { (milk) } \\
\text { week }\end{array}$ & $\begin{array}{l}\text { Peak } \\
\text { production } \\
\text { FPCM }^{1} \\
\text { kg/d }\end{array}$ \\
\hline 1 & 65 & Nov. '93-Jan. '94 & $2-8$ & 35 & $2 \ldots 12^{2}$ & 43.8 \\
\hline 2 & 82 & Sep. '93-May '94 & $2-12$ & 34 & $2 \ldots 12^{2}$ & 36.9 \\
\hline 3 & 42 & Nov. '93-Feb. '94 & $2-7$ & 35 & $2 \ldots 12^{2}$ & 31.3 \\
\hline 4 & 60 & Sep. '93-Nov. '93 & $2-9$ & 30 & $2 \ldots 12^{2}$ & 31.6 \\
\hline 5 & 98 & Aug. '93-Sep. '93 & $1-9$ & 56 & $2 \ldots 12^{2}$ & 31.1 \\
\hline 6 & 120 & Nov. '93-Aug. '94 & $1-3$ & 31 & $3 \ldots 12^{2}$ & 28.5 \\
\hline 7 & 71 & Sep. '93-Feb. '94 & $1-6$ & 37 & $2 \ldots 12^{2}$ & 29.3 \\
\hline 8 & 62 & Sep. '93-Nov. '93 & $1-7$ & 39 & $3 \ldots 9^{3}$ & 34.6 \\
\hline Total & 600 & & & & & \\
\hline
\end{tabular}

${ }^{1} \mathrm{FPCM} 4 \%$ fat, $3.2 \%$ protein corrected milk in lactation wk 5 .

${ }^{2}$ Milk sampled once every week starting in wk 1 or 2 .

${ }^{3}$ Milk sampled once every 4 wk.

$$
\begin{aligned}
& \times \mathrm{kg} \mathrm{milk}, \\
\mathrm{E}_{\text {maintenance }}= & 0.286 \times \mathrm{BW}^{0.75}, \text { and } \\
\mathrm{E}_{\text {milk }}= & 3.053 \times \mathrm{FPCM}^{+}+0.00504 \times \\
& \mathrm{FPCM}^{2} \quad\left(\mathrm{MJ}_{\text {nel }} / \mathrm{d}\right) .
\end{aligned}
$$

The following definition of estimated energy intake ( $\left.\mathrm{eE}_{\text {intake }}\right)$ was used:

$$
\begin{aligned}
\mathrm{eE}_{\text {intake }}= & \mathrm{eEB}+\mathrm{E}_{\text {requirement }} \\
= & \mathrm{eEB}+\mathrm{E}_{\text {milk }}+\mathrm{E}_{\text {maintenance }}+\mathrm{E}_{\text {growth }} \\
& +\mathrm{E}_{\text {pregnancy }}
\end{aligned}
$$

Energy requirement for pregnancy was set to zero because the predictions are based on test day information from the first 12 wk of lactation, during which no significant amount of energy is required for pregnancy. Energy for growth is relatively small and assumed constant for cows in first (4.144 $\mathrm{MJ}_{\text {nel }} / \mathrm{d}$ ) and cows in second lactation (2.072 $\left.\mathrm{MJ}_{\mathrm{nel}} / \mathrm{d}\right)$; cows with 3 or more lactations do not require energy for growth. However, maintenance is a major component of energy requirement and was therefore considered in the analysis in 2 ways: 1 ) as a constant assuming fixed BW for cows in parity groups $1,2,3$, and $\geq 4$ where the constant was the actual mean weight of cows across all trial herds; and 2) according to actual repeatedly measured $\mathrm{BW}$. The reason for this approach was that BW is not available in routinely collected herd test data, and the aim of this study was the validation of eEI based on herd test data. A comparison was therefore required between model estimation with actual BW (the ideal case) and without BW, assuming that BW was constant across herd (the field application). Thus, the calculations of total estimated energy intake for the constant and the variable approach were:

1) $\mathrm{eE}_{\text {intake_con }}=\mathrm{eEB}+\mathrm{E}_{\text {milk }}+$ constant $\mathrm{E}_{\text {maintenance }}+$

$$
\text { 2) } \mathrm{eE}_{\text {intake_var }}=\begin{aligned}
& \text { constant } \mathrm{E}_{\text {growth }} \\
& \text { eEB }+\mathrm{E}_{\text {milk }}+\text { measured } \mathrm{E}_{\text {maintenance }}+ \\
& \text { constant } \mathrm{E}_{\text {growth }} .
\end{aligned}
$$

For treated and control cows, weekly least square means were calculated for the following outcomes: eEB, FPCM, BW, ACAC, BHB, and energy intake for the 2 approaches $\left(\mathrm{eE}_{\text {intake_con }}\right.$ and $\left.\mathrm{eE}_{\text {intake_var }}\right)$. The calculations were adjusted for fixed effects of trial and parity and for the correlation between repeated weekly measurements on the same cow using GEE with an autoregressive correlation structure (Diggle et al., 1994). The model was:

$$
\begin{gathered}
\text { Outcome }=\text { intercept }+ \text { week } \\
\times \text { monensin }+ \text { parity }+ \text { trial }+ \text { error }
\end{gathered}
$$

The interaction term for week (of lactation relative to treatment start) $\times$ monensin was included to differentiate treated and control cows before and after the start of the supplementation with monensin.

After having estimated total energy intake, a fixed amount was deducted for maintenance and growth as described in option 1 above to obtain energy available for milk production ( $\left.\mathrm{eE}_{\text {intake|milk }}\right)$. This assumed that all requirement for maintenance and growth was covered by available feed energy. In reality, this is not always true when cows are in negative energy balance because some energy for maintenance and growth may be covered by mobilized body tissue. However, if the amount for energy estimated in this way is regarded as the minimum energy available for milk production, the comparison with actual FPCM can be used as an indicator for herd average feed efficiency. High efficiency would be reflected by a ratio FPCM/MJ eE $E_{\text {intake|milk }} \geq$ $0.314(=1 / 3.18)$, since the energy value per kilogram of FCPM is $3.18 \mathrm{MJ}$ eE $\mathrm{E}_{\text {intakelmilk, }}$, and this would indicate 
Table 2. Descriptive statistics of ketone bodies acetoacetate (ACAC) and beta-hydroxy-butyrate (BHB) in the serum, milk production performance, estimated energy balance, estimated energy intake, and BW of the cows in the study (600 cows, $\mathrm{N}$ = number of weekly repeated measurements, lactation wk 2 to 12 ; $\mathrm{STD}=$ standard deviation).

\begin{tabular}{|c|c|c|c|c|c|}
\hline & $\mathrm{N}$ & Mean & STD & Min & Max \\
\hline $\operatorname{ACAC}(\ln [\mu \mathrm{mol}])$ & 1882 & 4.49 & 0.70 & 1.79 & 7.64 \\
\hline $\mathrm{BHB}(\ln [\mu \mathrm{mol}])$ & 1881 & 6.45 & 0.48 & 4.56 & 8.76 \\
\hline Milk $(\mathrm{kg} / \mathrm{d})$ & 5760 & 31.94 & 7.07 & 8.90 & 53.40 \\
\hline Milk fat $(\%)$ & 5760 & 4.05 & 0.89 & 1.33 & 9.21 \\
\hline Milk protein $(\%)$ & 5760 & 3.20 & 0.36 & 1.07 & 4.80 \\
\hline Fat-protein corrected milk (kg/d) & 5760 & 31.70 & 7.17 & 9.32 & 55.21 \\
\hline Estimated energy balance $\left(\mathrm{MJ}_{\mathrm{NEL}} / \mathrm{d}\right)$ & 5760 & 18.62 & 20.64 & -99.12 & 94.71 \\
\hline $\begin{array}{l}\text { Estimated energy intake for milk } \\
\text { production and maintenance }\left(\mathrm{MJ}_{\mathrm{NEL}} / \mathrm{d}\right)\end{array}$ & 5760 & 118.31 & 19.10 & 27.03 & 158.43 \\
\hline BW & & & & & \\
\hline$(\mathrm{n}=117$ cows $)$ & 376 & 550.52 & 56.49 & 374.00 & 693.00 \\
\hline$(\mathrm{n}=203$ cows $)$ & 1073 & 585.10 & 57.99 & 364.00 & 710.00 \\
\hline$(\mathrm{n}=150$ cows $)$ & 840 & 605.84 & 51.95 & 386.00 & 745.00 \\
\hline$(\mathrm{n}=130$ cows $)$ & 847 & 641.10 & 63.41 & 396.00 & 799.00 \\
\hline
\end{tabular}

that part of the energy in milk was derived from the mobilization of body tissue. Using the study data as an example, the effect of parity and trial (herd) was evaluated by the feed conversion ratio of $\mathrm{kg}$ FPCM per $\mathrm{MJ}_{\text {nel }} \mathrm{eE}_{\text {intakelmilk. All calculations used the statistical }}$ procedure MIXED of SAS (release 8.02, SAS 2002).

All models were tested for distributional and homogeneous variance assumptions and outliers. Significance was declared at $P<0.05$ if not otherwise stated.

\section{RESULTS}

Mean, standard deviation, and range of the study parameters are shown in Table 2. All parameter means of treatment and control cows were not different before supplementation $(P>0.1)$.

Table 3 shows differences between monensin and control cows during the period of supplementation. After the start of supplementation, the milk yield was, on average, $1.0 \mathrm{~kg} / \mathrm{d}$ higher in monensin treated cows than in control cows $(P=0.01)$. Ketone bodies (ACAC and $\mathrm{BHB}$ ), the fat:protein ratio, and percentage milk fat were significantly reduced by monensin $(P<0.001)$. Differences between BW means of parity groups 1,2 , 3 , and 4+ ranged from 38 to $50 \mathrm{~kg}$ and were highly significant $(P<0.0001)$ except for the difference between parity groups 3 and $4+(15.4 \mathrm{~kg}, P=0.027)$. There was no difference in energy requirement for maintenance based on actual BW due to supplementation. The milk protein concentration and solid corrected milk production were unaffected by treatment with monensin. The estimated energy intake $\left(\mathrm{eE}_{\text {intake }}\right)$ was $1.9 \mathrm{MJ}_{\text {nel }}$ higher $(P=0.015)$ regardless of whether maintenance was based on constant or measured BW. The estimated energy balance was $1.6 \mathrm{MJ}_{\text {nel }}$ higher in the supplemented group, but the latter difference was only mar-

Table 3. Difference of least square means of ketone bodies acetoacetate (ACAC) and beta-hydroxy-butyrate (BHB) in the serum, milk production performance, estimated energy balance, and estimated energy intake ${ }^{1}$ between monensin treated and control cows during the treatment period (SE = standard error of the mean difference monensin - control).

\begin{tabular}{|c|c|c|c|c|}
\hline & $\mathrm{DF}$ & $\begin{array}{l}\text { Mean difference } \\
\text { (Monensin - Control) }\end{array}$ & $\mathrm{SE}$ & $\mathrm{p}$ \\
\hline $\operatorname{ACAC}(\ln [\mu \mathrm{mol}])$ & 1037 & -0.070 & 0.032 & 0.0306 \\
\hline $\mathrm{BHB}(\ln [\mu \mathrm{mol}])$ & 1037 & -0.145 & 0.030 & $<0.0001$ \\
\hline Milk $(\mathrm{kg} / \mathrm{d})$ & 3591 & 1.075 & 0.439 & 0.0148 \\
\hline Milk fat (\%) & 3591 & -0.234 & 0.044 & $<0.0001$ \\
\hline Milk protein $(\%)$ & 3591 & -0.008 & 0.021 & 0.7182 \\
\hline Ratio milk fat $(\%) /$ milk protein $(\%)$ & 3591 & -0.074 & 0.010 & $<0.0001$ \\
\hline Fat-protein corrected milk FCPM (kg/d) & 3378 & 0.097 & 0.373 & 0.7949 \\
\hline Estimated energy balance eEB $\left(\mathrm{MJ}_{\mathrm{NEI}} / \mathrm{d}\right)$ & 3378 & 1.585 & 0.871 & 0.0691 \\
\hline Estimated energy intake $\mathrm{eE}_{\text {intake con }}\left(\mathrm{MJ}_{\mathrm{NEL}} / \mathrm{d}\right)^{1}$ & 3591 & 1.881 & 0.590 & 0.0015 \\
\hline Estimated energy intake $\mathrm{eE}_{\text {intake var }}\left(\mathrm{MJ}_{\mathrm{NEI}} / \mathrm{d}\right)^{2}$ & 1934 & 1.871 & 0.558 & 0.0146 \\
\hline Energy requirement for maintenance & 1934 & 0.155 & 0.237 & 0.513 \\
\hline
\end{tabular}

${ }^{1}$ Calculated as eEB $+\mathrm{E}_{\text {milk }}+$ constant $\mathrm{E}_{\text {maintenance }}+$ constant $\mathrm{E}_{\text {growth }}$.

${ }^{2}$ Calculated as $\mathrm{eEB}+\mathrm{E}_{\text {milk }}+$ measured $\mathrm{E}_{\text {maintenance }}+$ constant $\mathrm{E}_{\text {growth }}$. 


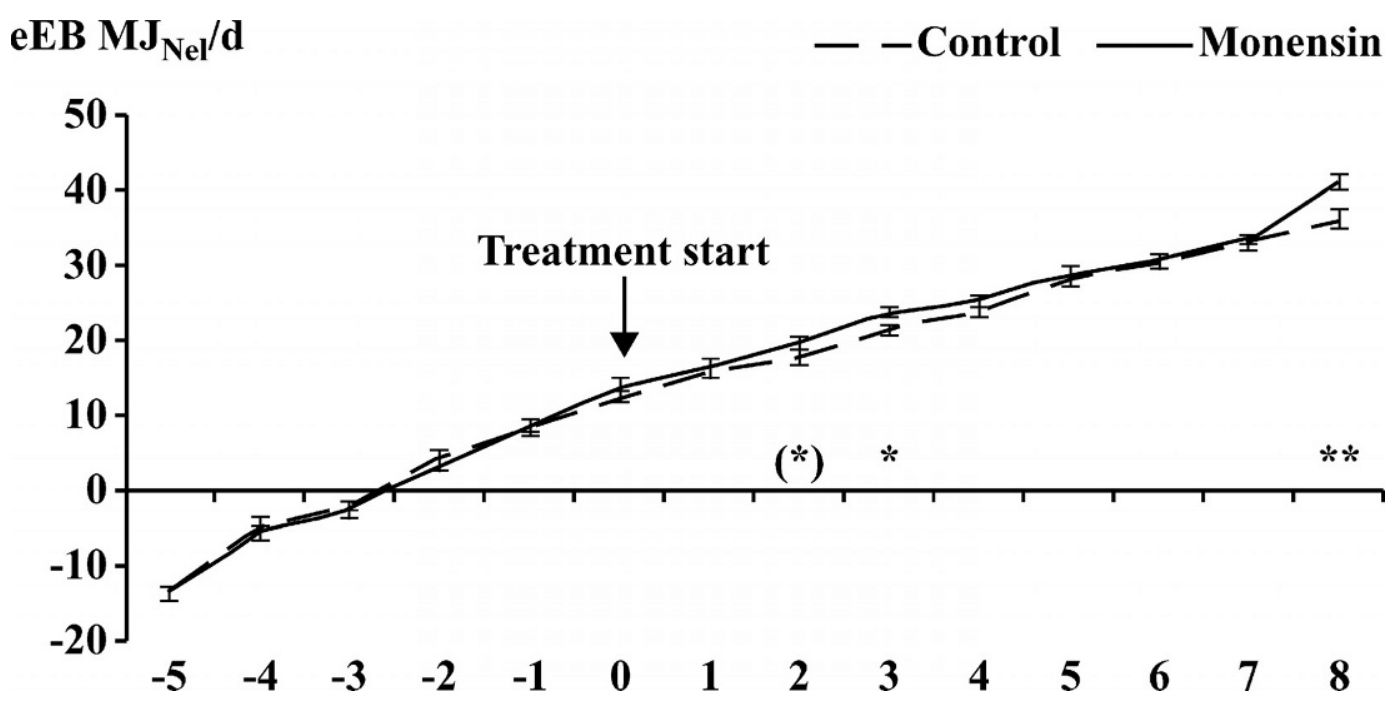

Figure 1. Weekly least square means of estimated energy balance (equation 1) for cows supplemented with monensin and control cows during lactation wk 2 to $12(\mathrm{n}=5760 ; 600$ cows $)$; vertical bars indicate standard errors; differences between monensin and control indicated as: $(*)=P<0.1 ; *=P<0.05 ; * *=P<0.01$

ginally significant $(P=0.07)$. Figure 1 shows that the estimated energy balance was similar for treated and control cows before the start of the monensin supplementation period but different in wk 2,3 , and 8 thereafter. Independent of the consideration of maintenance requirement, the $\mathrm{eE}_{\text {intake }}$ of treated and control cows was not different before treatment start, but was significantly different in every week of the treatment period through to the 12th week of lactation (Figures 2 and 3). The level of significance for estimated energy intake was somewhat lower when maintenance requirement was based on actual BW compared with constant BW, but this was probably due to lower power, as BW was not measured in every week of the study. However, both calculations included measurements from all 600 cows.

Fat- and protein-corrected milk and $\mathrm{eE}_{\text {intake|milk in- }}$ creased from parities 1 to 3 , whereas there was no differ-

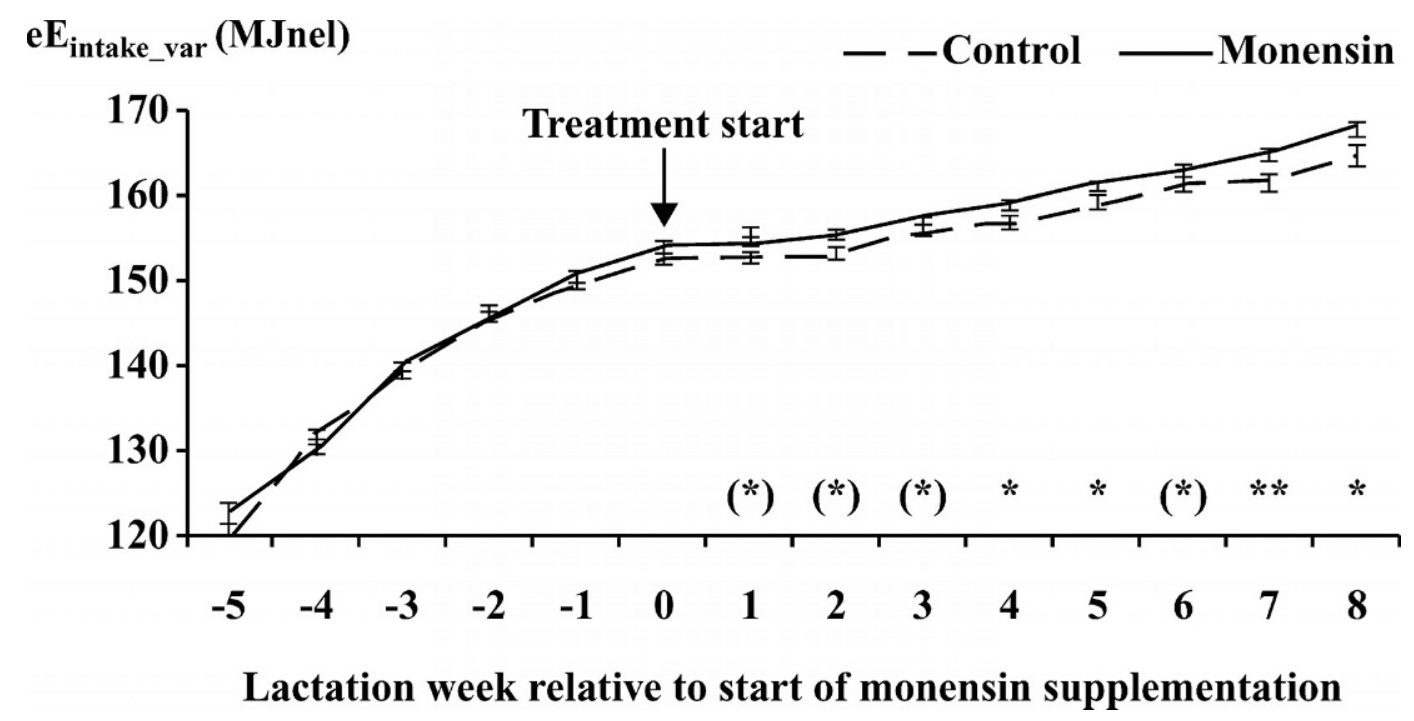

Figure 2. Weekly least square means of estimated energy intake in which maintenance was based on measured $\mathrm{BW}\left(\mathrm{eE}_{\text {intake }}\right.$ var $)$ for cows supplemented with monensin and control cows during lactation wk 2 to 12 ( $\mathrm{n}=3136$; 600 cows); vertical bars indicate standard errors; differences between monensin and control indicated as: $(*)=P<0.1 ; *=P<0.05 ; * *=P<0.01 ; * * * P<0.001$. 


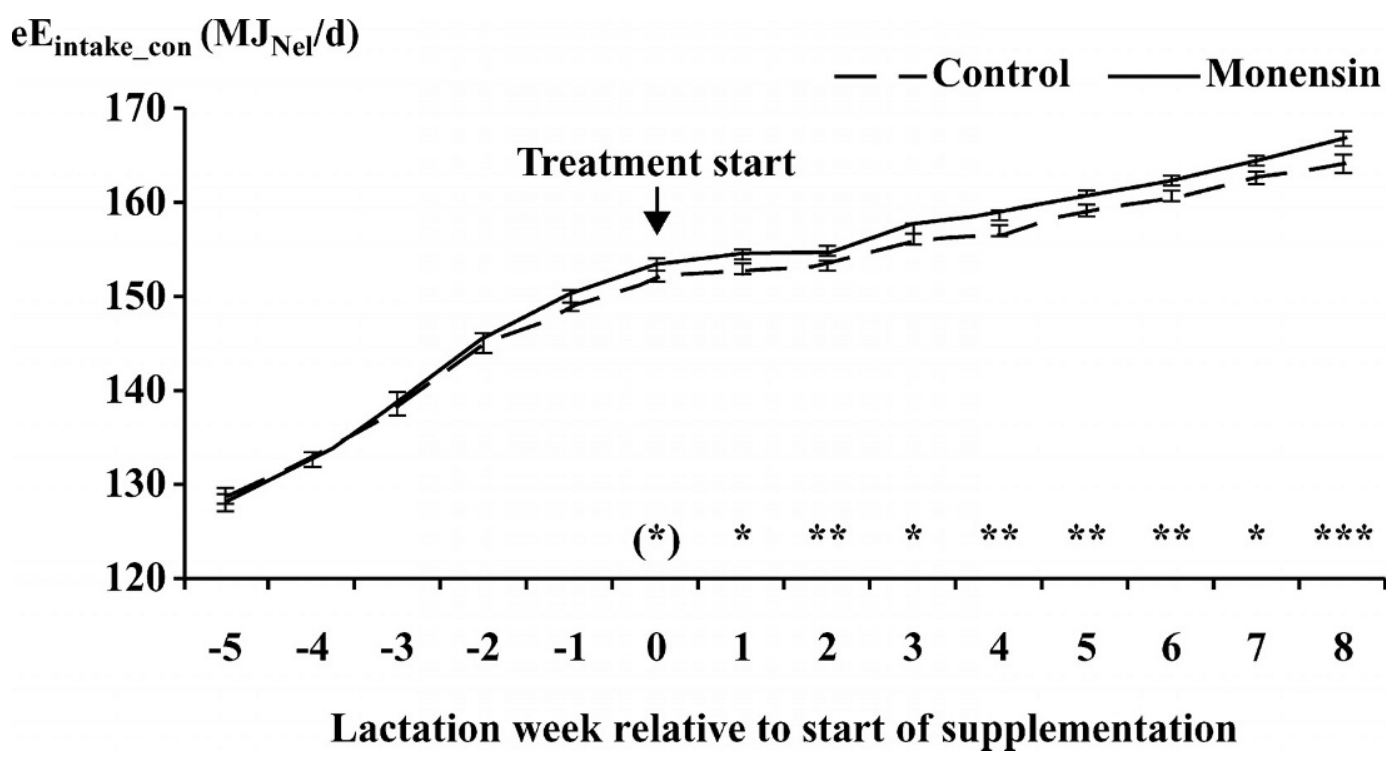

Figure 3. Weekly least square means of estimated energy intake in which maintenance was based on constant $\mathrm{BW}$ (eE $\mathrm{E}_{\text {intake con }}$ ) for cows supplemented with monensin and control cows during lactation wk 2 to $12(\mathrm{n}=5760 ; 600$ cows); vertical bars indicate standard errors; differences between monensin and control indicated as: $(*)=P<0.1 ; *=P<0.05$; ** $=P<0.01$; *** $=P<0.001$.

ence between parities 3 and older cows. However, the energy intake for milk production of cows with 4 or more lactations was estimated to be $5 \mathrm{MJ}_{\text {nel }} / \mathrm{d}$ higher than cows with 3 lactations without an increase in milk production. This resulted in a lower feed conversion efficiency of older cows $(P<0.001)$. Based on $\mathrm{eE}_{\text {intake|milk, }}$, the feed conversion efficiency was highest in first lactation cows (Table 4). Solid-corrected milk production depended to a great extent on the estimated feed intake in all parity groups and in all trials. This was associated with the feed conversion efficiency that was highest in trials with high average milk production and vice versa. However, feed conversion efficiency did not always follow this trend. In 3 trial herds with similar milk production, the feed conversion efficiency in trial herd 5 was lower than in trial herds 4 and 6 due to higher eEI (Table 4).

With the exception of the ratio responses (FP, feed efficiency), all residuals diagnostics of all models did not provide evidence for concern about model assump-

Table 4. Least square means of fat and protein-corrected milk production (FPCM), estimated energy intake for milk production $\left(\mathrm{eE}_{\text {intakelmilk }}\right.$ ), and feed conversion efficiency $\left(\mathrm{FPCM} / \mathrm{e} \mathrm{E}_{\text {intakelmilk }}\right.$ ) for parity (4+ = four and higher) and trials (herd), adjusted for the effect of monensin supplementation $\times$ week of lactation.

\begin{tabular}{llll}
\hline & $\begin{array}{l}\text { FPCM } \\
\mathrm{kg} / \mathrm{d}\end{array}$ & $\begin{array}{l}\mathrm{eE}_{\text {intakelmilk }} \\
\mathrm{MJ} J_{\mathrm{NEL}} / \mathrm{d}\end{array}$ & $\begin{array}{l}\text { Feed conversion } \\
\text { efficiency } \\
\mathrm{kg} / \mathrm{MJ} J_{\text {NEL }}\end{array}$ \\
\hline Parity & & \\
1 & $26.4^{\mathrm{a}}$ & $86.5^{\mathrm{a}}$ & $0.306^{\mathrm{a}}$ \\
2 & $31.8^{\mathrm{b}}$ & $120.5^{\mathrm{b}}$ & $0.263^{\mathrm{b}}$ \\
3 & $34.4^{\mathrm{c}}$ & $124.3^{\mathrm{c}}$ & $0.275^{\mathrm{c}}$ \\
$4+$ & $34.1^{\mathrm{c}}$ & $129.2^{\mathrm{d}}$ & $0.261^{\mathrm{b}}$ \\
Trial Herd & & & \\
1 & $39.4^{\mathrm{a}}$ & $120.3^{\mathrm{a}}$ & $0.330^{\mathrm{a}}$ \\
2 & $33.6^{\mathrm{b}}$ & $114.1^{\mathrm{b}}$ & $0.298^{\mathrm{b}}$ \\
3 & $29.5^{\mathrm{c}}$ & $119.4^{\mathrm{a}, \mathrm{f}}$ & $0.253^{\mathrm{c}}$ \\
4 & $27.6^{\mathrm{d}}$ & $112.1^{\mathrm{c}, \mathrm{d}, \mathrm{e}}$ & $0.257^{\mathrm{c}}$ \\
5 & $28.9^{\mathrm{c}, \mathrm{e}, \mathrm{f}}$ & $119.6^{\mathrm{a}, \mathrm{f}}$ & $0.244^{\mathrm{e}}$ \\
6 & $29.0^{\mathrm{e}, \mathrm{f}}$ & $111.0^{\mathrm{d}}$ & $0.265^{\mathrm{d}}$ \\
7 & $29.6^{\mathrm{c}, \mathrm{f}}$ & $110.1^{\mathrm{e}}$ & $0.273^{\mathrm{f}}$ \\
8 & $33.8^{\mathrm{b}}$ & $117.8^{\mathrm{f}}$ & $0.292^{\mathrm{b}}$ \\
\hline
\end{tabular}

a,b,c,d,e,f Different superscripts indicate significant differences between means within column and parity or column and trial $(P<0.05)$. 
tions or outliers. The distributions of residuals of the ratio response models showed slight kurtosis, but were symmetric, and variances were homogeneous. Hence if any, the resulting effects on inferences were extremely small.

\section{DISCUSSION}

Cows treated with monensin had a more positive energy status than control cows in this as in other studies (Abe et al., 1994; Stephenson et al., 1997; Duffield et al., 1998). The better energy status was reflected in this study by higher milk yield, lower milk fat percentage, and lower serum ketone bodies. As lower milk yield indicated a lower extent of body fat mobilization and higher milk yield, associated with more lactose production, was to a great extent derived from feed energy, it was unlikely that DMI had decreased due to monensin in this study. Energy status was most likely the only difference between treatment and control cows because firstly, treatment was allocated randomly after blocking for parity, production level, and time of calving, and secondly, parity and trial herd were controlled in the analysis. Because the milk protein percentage remained constant and the milk fat percentage decreased by $0.2 \%$, the increase of $1 \mathrm{~kg}$ of milk yield due to monensin was effectively associated with an increase in lactose production, while milk solids were unaffected. Milk volume and percentage of milk lactose are closely correlated. Milk lactose depends on the availability of blood glucose, the main metabolic substrate for energy. Monensin increases energy precursors in the rumen (Chen and Wolin, 1979), and these enhance gluconeogenesis in the liver (Lean et al., 1992). Thus, there is an energy based, metabolic pathway for an increase in milk yield due to supplementation with monensin.

Energy balance has been compared with test day information before resulting in a high correlation $(>0.60)$ between EB and a change in the milk fat percentage during the first 26 DIM (De Vries and Veerkamp, 2000). In this study, eEB reflected the energy difference between supplemented and control cows significantly in wk 2, 3, and 8 after the start of supplementation, while eEB was the same before supplementation: monensin cows had higher eEB than control cows. The coefficients for milk yield and the fat-protein ratio were both negative in the eEB equation. Hence, lower milk fat increases and higher milk yield decreases eEB. Based on a change of one standard deviation observed in the present data, a higher fat-protein ratio decreased eEB to a greater extent than lower milk yield increased it. This differed from our earlier study of a group of 72 cows in which we suggested that one standard deviation of either parameter had a similar impact on eEB (Heuer et al., 2001a). Apparently, different rations, and perhaps different cows, had variable impacts on the energy metabolism.

The difference in estimated energy intake ( $\mathrm{eE}_{\text {intake|milk }}$ ) between monensin-supplemented and control-cows was highly significant throughout the 8-wk treatment period (lactation wk 5 to 12 ). Thus, $\mathrm{eE}_{\text {intakelm- }}$ ilk reflected the difference between supplemented and control cows better than eEB. Because eEB depends on milk production but $\mathrm{eE}_{\text {intake|milk }}$ does not, $\mathrm{eE}_{\text {intake|milk }}$ was more accurate because it was adjusted for milk production. To explain this more clearly: a herd with high milk production is likely to have a profoundly negative energy balance, but when energy balance reaches critical negative levels, cows may produce less milk to compensate for metabolic demands when the capacity of mobilizing body reserves tends to be exhausted. With low milk production, energy balance appears adequate or even high because of low energy requirement. Thus, a high energy balance is either an indication of a good energy status (hence an effective ration) or a consequence of low milk production, possibly preceded by an extremely negative energy balance. In contrast, eEI is obtained by adjusting eEB by actual milk production, hence $\mathrm{eE}_{\text {intakelmilk }}$ is independent of milk production. It is therefore an unbiased indicator for the conversion of feed energy into absorbed, metabolizable energy available for milk production. Hence in our study, the weekly comparisons of $\mathrm{eE}_{\text {intakelmilk }}$ between monensin and control cows were clearly in favor of the supplemented group. The fact that test day information (i.e., milk control data) could be used to differentiate the existing energy difference between supplemented and control cows encourages the use of the estimation model for regular ration control of postpartum cows.

The interpretation of $\mathrm{eE}_{\text {intakelmilk }}$ was absorbed energy available for milk production. Given that $1 \mathrm{~kg}$ of FPCM is equivalent to approximately $3 \mathrm{MJ}_{\text {nel }}$, the expected FPCM is one third of the estimated energy intake. Since $\mathrm{eE}_{\text {intakelmilk }}$ is the sum of eEB plus the energy equivalent of FPCM, a high producing herd with average concentrations of fat and protein in milk-and therefore an average fat-protein ratio-will have similar actual and expected FPCM. As the fat-protein ratio increases, both eEB and $\mathrm{eE}_{\text {intake|milk }}$ decrease, and actual FPCM is higher than expected FPCM. Consequently, the average cow in the herd is in negative energy balance and expected to mobilize body reserves to provide energy for milk production. The larger the difference between actual and expected FPCM, the higher the metabolic stress for the average cow, and the higher the risk for production diseases (Heuer et al., 2001b).

Following this concept, the ratio of actual FPCM produced per estimated $\mathrm{MJ}_{\text {nel }}$ intake is defined as feed 
conversion efficiency (Table 4). For trial herd 1, the feed conversion efficiency was slightly more than the expected 0.33 . The other 7 trial herds had feed conversion efficiencies lower than one third ( 0.24 to 0.30 ). Even though the actual standard milk production was included in the calculation of $\mathrm{eE}_{\text {intakelmilk, }} \mathrm{eEI}$ and feed conversion efficiency were not highly correlated with milk production. The apparent reason is that cows that have been selected for high milk production over several decades tend to maintain production, while energy intake may be suboptimal, resulting in negative energy balance and metabolic stress. We had shown this in an earlier study where the correlation between eEB and milk production was lower than the correlation between eEB and DMI (Heuer et al., 2000). Therefore, the feed conversion efficiency estimated by the model likely reflects the actual energy efficiency of the ration. Feed efficiency of first calving cows was higher than that of older cows, possibly due to lower energy balance. In our earlier study on model development, measured energy balance in first lactation cows of a different herd was indeed lower than that of older cows (Heuer et al., 2000).

It is concluded that the model provides an unbiased $\mathrm{eEI}$ available for lactation and suggested that $\mathrm{eE}_{\text {intake|m- }}$ ilk can be used at herd level as a tool to monitor energy intake of dairy herds in early lactation. However, the formulas for the conversion of test-day data to eEB, $\mathrm{eE}_{\text {intakelmilk }}$, and feed conversion efficiency has been developed for cows with a relatively high annual production of $10,500 \mathrm{~kg}$ of standard milk, which was achieved through a high level of supplementary dairy concentrates. The prediction formula may therefore apply primarily to such systems. Pasture-fed dairy cows produce roughly half as much. It is therefore unlikely that the same formula is valid for dairy cows in pasture-based systems such as in New Zealand or Australia.

Clearly, the prediction of energy intake from DHI test day information is still far from its practical application in commercial herds. While it may be assumed that only the intercept in the eEB equation may have to be modified, further evidence is required to validate and possibly adjust the prediction formula for pasturefed dairy cows. Moreover, predictions of herd means and variability between cows need to be evaluated from a large number of reference herds and compared with possible confounding effects (production type, herd size, milk production, genetic merit, breed, average BW, feed composition, and main energy source). In a sample of herds, the predictions would have to regressed on presumably correlated effects at cow level like BCS, BW, change in BCS and BW, ketone body concentrations in blood or milk, and clinical disease related to energy metabolism [e.g., retained fetal membranes, ketosis, displaced abomasum (Duffield et al., 2002), mastitis, and lameness (Peterse, 1980; Suriyasathaporn et al., 2000)]. Finally, standards need to be developed that describe expected means and variability of herd level predictions. Given that the predictions turn out to be sufficiently robust, the idea is to present predictions to farmers in graphical form similar to Figure 3, with a standard expected curve along with limits of standard deviations in the background and a mean observed curve plus a density plot of individual cows for the individual herd. As all required information is already available from DHI databases, no extra costs are required to generate such reports once computers have been set up accordingly to process test day data.

\section{ACKNOWLEDGMENTS}

The manuscript greatly benefited from reviews done by Prof. C. W. Holmes of the Institute of Veterinary, Animal and Biomedical Sciences, Massey University (New Zealand), by Associate Prof. Y. H. Schukken of the Veterinary Faculty, Cornell University, New York, and by W. M. Van Straalen, Institute of Animal Nutrition, Lelystad, The Netherlands. The author gratefully acknowledges their contributions.

\section{REFERENCES}

Abe, N., I. J. Lean, A. Rabiee, J. Porter, and C. Graham. 1994. Effects of sodium monensin on reproductive performance of dairy cattle. II. Effects on metabolites in plasma, resumption of ovarian cyclicity and oestrus in lactating cows. Aust. Vet. J. 71:277-282.

Chen, M., and M. J. Wolin. 1979. Effect of monensin and lasalocidsodium on the growth of methanogenic and rumen saccharolytic bacteria. Appl. Environ. Microbiol. (since 1976) Arch. Biochem. Biophys. 38:72-77.

Diggle, P. J., K.-Y. Liang, and S. L. Zeger. 1994. Analysis of longitudinal data. Clarendon Press, Oxford, UK.

De Kruif, A., R. Mansfeld, and M. Hoedemaker. 1998. Tierärztliche Bestandsbetreuung beim Milchrind. Ferdinand Enke Verlag, Stuttgart, Germany.

De Vries, M. J., and R. F. Veerkamp. 2000. Energy Balance of Dairy Cattle in Relation to Milk Production Variables and Fertility. J. Dairy Sci. 83:62-69.

Drackley, J. K. 1999. Biology of dairy cows during the transition period: The final frontier? J. Dairy Sci. 82:2259-2273.

Duffield, T. F., D. Sandals, K. L. Leslie, K. Lissamore, B. W. McBride, J. H. Lumsden, P. Dick, and R. Bagg. 1998. Efficacy of monensin for the prevention of subclinical ketosis in lactating dairy cows. J. Dairy Sci. 81:2866-2873.

Duffield, T. F., R. Bagg, L. DesCoteaux, E. Bouchard, M. Brodeur, D. DuTremblay, G. Keefe, S. LeBlanc, and P. Dick. 2002. Prepartum monensin for the reduction of energy associated disease in postpartum dairy cows. J. Dairy Sci. 85:397-405.

Gearhart, M. A., C. R. Curtis, H. N. Erb, R. D. Smith, C. J. Sniffen, L. E. Chase, and M. D. Cooper. 1990. Relationship of changes in condition score to cow health in Holsteins. J. Dairy Sci. 73:3132-3140.

Goff, J. P., and R. L. Horst. 1997. Physiological changes at parturition and their relationship to metabolic disorders. J. Dairy Sci. 80:1260-1268.

Heuer, C., Y. H. Schukken, and P. Dobbelaar. 1999. Postpartum body condition score and first milk test results as predictors of disease, fertility, production, and culling. J. Dairy Sci. 82:295-304. 
Heuer, C., W. M. Van Straalen, Y. H. Schukken, A. Dirkzwager, and J. P. T. M. Noordhuizen. 2000. Prediction of energy balance in a high yielding dairy herd in early lactation: Model development and precision, Livest. Prod. Sci. 65:91-105.

Heuer, C., W. M. Van Straalen, Y. H. Schukken, A. Dirkzwager, and J. P. T. M. Noordhuizen. 2001a. Prediction of energy balance in a high yielding dairy cow with test day information. J. Dairy Sci. 84:471-481.

Heuer, C., Y. H. Schukken, L. J. Jonker, J. I. D. Wilkinson, and J. P. T. M. Noordhuizen. 2001b. Effect of monensin on blood ketone bodies, incidence and recurrence of disease and fertility in high yielding dairy cows. J. Dairy Sci. 84:1085-1097.

Kennelly, J. J., B. Robinson, and G. R. Khorasani. 1999. Influence of carbohydrate source and buffer on rumen fermentation characteristics, milk yield and milk composition in early-lactation Holstein cows. J. Dairy Sci. 82:2486-2496.

Lean, I. J., M. L. Bruss, R. L. Baldwin, and H. F. Troutt. 1992. Bovine ketosis: A review. II. Biochem. Prevention. Vet. Bull. 62:1-14.

Mottram, T. 1997. Automatic monitoring of the health and metabolic status of dairy cows. Livest. Prod. Sci. 48:209-217.

Peterse, D. J. 1980. Nutrition and ulcers of the sole in cattle. Tijdschr. Diergeneeskd. 104:966.

Phipps, R. H., J. I. D. Wilkinson, L. J. Jonker, M. Tarrant, A. K. Jones, and A. Hodge. 2000. Effect of monensin on milk production of Holstein-Friesian dairy cows. J. Dairy Sci. 83:2789-2794.

Reksen, O., Y. T. Gröhn, O. S. Havrevoll, T. Bolstad, A. Waldmann, and E. Ropstad. 2001. Influence of concentrate allocation and energy balance on postpartum ovarian activity in Norwegian cattle. J. Dairy Sci. 84:1060-1068.
SAS Institute Inc., 2002. SAS/STAT Software: Changes and enhancements through release 8.02, Statistical Analysis Systems Institute Inc., Cary, NC.

Senatore, E. M., W. R. Butler, and P. A. Oltenacu. 1996. Relationship between energy balance and post-partum ovarian activity and fertility in first lactation dairy cows. Anim. Prod. 62:17-23.

Simensen, E., K. Halse, P. Gillund, and B. Lutnaes. 1990. Ketosis treatment and milk yield in Dairy cows related to milk acetone levels. Acta Vet. Scand. 31:433-440.

Stephenson, K. A., I. J. Lean, M. L. Hyde, M. A. Curtis, J. K. Garvin, and L. B. Lowe. 1997. Effect of monensin on the metabolism of periparturient dairy cows. J. Dairy Sci. 80:830-837.

Suriyasathaporn, W., C. Heuer, E. N. Noordhuizen-Stassen, and Y. H. Schukken. 2000. Hyperketonemia and the impairement of udder defence: a review. Vet. Res. 31:397-412.

Svennersten-Saunja, K., L.-O. Sjaunja, J. Bertilsson, and H. Wiktorsson. 1997. Use of regular milking records versus daily records for nutrition and other kinds of management. Livest. Prod. Sci. 48:167-174.

Van Es, A. J. H. 1978. Feed evaluation for ruminants. I. The system in use from May 1977 onwards in the Netherlands. Livest. Prod. Sci. 5:331-345.

Van Der Honing, Y., and G. Alderman. 1988. Livestock feed resources and feed evaluation in Europe. III 2. Ruminants. Livest. Prod. Sci. 19:217-278.

Van Der Werf, J. H. J., L. J. Jonker, and J. K. Oldenbroek. 1998. Effect of monensin on milk production by Holstein and Jersey cows. J. Dairy Sci. 81:427-433. 